Adams, M. E. \& Postgate, J. R. (1959). J. gen. Microbiol. 20, 252-257

\title{
A New Sulphate-Reducing Vibrio
}

\author{
By MARY E. ADAMS AND J. R. POSTGATE \\ National Chemical Laboratory, Teddington, Middlesex
}

SUMMARY: An obligately anaerobic sulphate-reducing vibrio (NCIB 8382) isolated from soil from Singapore differs from known species of sulphate-reducing bacteria. The organism is relatively large, with one or two flagella, Gram-negative, lacks hydrogenase and pigments characteristic of Desulphovibrio desulphuricans, though an insoluble cytochrome is present. It grows with lactate or pyruvate, but is unable to metabolize acetate, propionate or butyrate; it reduces sulphate, sulphite or thiosulphate but not tetrathionate. Sporulation is rare but has been observed. The name Desulphovibrio orientis is proposed for this organism.

The number of different organisms believed to be capable of dissimilatory sulphate reduction is small. Baars (1930) devoted the opening chapter of his thesis to a survey of organisms reported earlier and concluded that all the better-authenticated ones corresponded to Beijerinck's Spirillum desulphuricans (Beijerinck, 1895) or the other two species: S. aestuarii (van Delden, 1903); $S$. thermodesulphuricans (Elion, 1925). (The generic name of this group has at various times been Spirillum, Microspira, Vibrio, Sporovibrio; at present Desulphovibrio is used most widely.) Baars's thesis included evidence that the species aestuarii and thermodesulphuricans were variants of the type species desulphuricans, which was able to utilize a variety of carbon sources but not butyrate, propionate or acetate. Baars introduced a new species rubentschikii, which was distinguished by being able to utilize these fatty acid salts, and a variant, rubentschikii var. anomalous able to utilize butyrate or propionate but not acetate. Though Baars's views were disputed in certain details (e.g. ZoBell, 1948), the opinion that dissimilatory sulphatereducing bacteria were confined to the one genus now called Desulphovibrio was widely accepted for about a quarter of a century. Occasional reports were made of sulphate-reducing organisms outside the genus Desulphovibrio: HvidHansen's (1951) Desulphoristella was lost soon after isolation, and Prévot's sulphate-reducing clostridia (Prévot, 1948) lost their ability to reduce sulphate on transfer in laboratory media. Campbell, Frank \& Hall (1957) showed that the species thermodesulphuricans is in fact Clostridium nigrificans and that the evidence obtained by Baars and later by Starkey (1938), indicating that it was a variant of desulphuricans, must have been wrongly interpreted. This observation required the re-classification of an existing type but not the introduction of a new one.

The present paper reports the isolation of a species of dissimilatory sulphate-reducing bacterium which does not fit into any pre-existing species, and for which the name Desulphovibrio orientis is proposed. 


\section{ISOLATION OF THE STRAIN}

A soil sample was received at this laboratory from the neighbourhood of a rising main at Sungei Whampoa, Rangoon Road, Singapore. An enrichment culture prepared by the procedure of Butlin, Adams \& Thomas (1949) showed considerable blackening at $30^{\circ}$ but none at $55^{\circ}$. The enrichment culture at $30^{\circ}$ contained no forms typical of Desulphovibrio desulphuricans; a considerable population of large slightly curved rods, often paired, was present; a few spore-forming rods were also seen. Colony isolation in medium $\mathbf{A}$ of Butlin et al. (1949) ultimately yielded a homogeneous culture of the curved organisms; no aerobes were detected by plating out on glucose peptone agar and no anaerobes apart from sulphate-reducing bacteria were detected in deep nutrient agar (Postgate, 1953). The organism grew erratically in either medium $\mathrm{C}$ or in medium $\mathrm{A}$ of Butlin et al. (1949); when these media were supplemented with thiolacetate $(0.01-0.02 \%, w / v)$ the organism grew regularly. It has been freeze-dried and deposited with the National Collection of Industrial Bacteria (NCIB) as organism no. $\mathbf{8 3 8 2}$.

Distribution. Enrichment cultures made from two other soil samples from the same site yielded the new type of sulphate-reducing organism but typical Desulphovibrio desulphuricans was not observed. One soil sample yielded thermophilic sulphate-reducing bacteria typical of Clostridium nigrificans. A fourth sample from Ulu Pandan, some 4 miles away, yielded the new type and from it a second pure culture was isolated (NCIB 8445). Samples taken three years later from the original sites still yield the new organisms, so did one from the McRitchie reservoir five miles away. Samples from neighbouring watercourses, cultivated soil and from the sea at Singapore yielded ordinary D. desulphuricans. Enrichment cultures made from soil near a termite comb in Kanpur, India, and from a marshy desert in West India also yielded the new organism.

Morphology. The organism was a fat rod, often slightly curved, sometimes paired or in short chains; mean dimensions: $4.85 \times 1 \cdot 4 \mu$. The organisms were uniformly Gram-negative and staining procedures provided no evidence for capsules. Non-progressive 'twisting and turning' motion was sometimes seen and was particularly marked in preparations taken from colonies in agar media. Cultures 5 or more days after growth contained a considerable number of organisms which showed granulated cytoplasm; forms with a single central or near-central granule were sometimes seen.

Preparations stained with Casares-Gil stain showed many organisms with one or two flagella, and forms which appeared peritrichous were often seen. Dr A. R. Prévot kindly examined cultures for us and came to the following conclusions: '.. la forme la plus fréquent est le cil unique polaire ou parapolaire. Puis vient en deuxième position la ciliature bipolaire, enfin moins fréquente la ciliature en apparence péritriche 3 à 4 cils. Mais si on analyse minutieusement les formes à 3 ou 4 cils on s'aperçoit que ce sont des diplovibrions ou des chainettes de vibrions.'

Cultivation. The organism showed growth after 36-72 hr. when inoculated 
into the media mentioned above, when thiolacetate was present. Cysteine, which has been used for poising the $E_{h}$ value of cultures of Desulphovibrio desulphuricans (Grossman \& Postgate, 1953), was not as satisfactory in promoting consistent growth of the strain as was thiolacetate; $\mathrm{Na}_{2} \mathrm{~S}$ could be used in place of thiolacetate but was not desirable when excess ferrous ion was present in the medium. Cultures were incubated at $30^{\circ}$ in McIntosh \& Fildes anaerobic jars filled with $\mathrm{H}_{2} 99 \%(\mathrm{v} / \mathrm{v})+\mathrm{CO}_{2} 1 \%(\mathrm{v} / \mathrm{v})$, in wholly filled and stoppered bottles, or in stoppered vessels made anaerobic with a cottonwool plug containing pyrogallol (sat.) $+\mathrm{Na}_{2} \mathrm{CO}_{3}$ (sat.). The $\mathrm{pH}$ range in which most rapid growth in medium $\mathrm{C}$ occurred was $6 \cdot 5-7 \cdot 0( \pm 0 \cdot 2)$; growth did not occur outside the limits $\mathrm{pH} 6 \cdot 0$ and $8 \cdot 0$.

The final yield of organisms in medium $\mathrm{C}$ was equivalent to $200-250 \mu \mathrm{g}$. dry wt. organisms $/ \mathrm{ml}$. (about two-thirds of the yield of Desulphovibrio desulphuricans in a similar medium). When the yeast extract $(0.1 \%, \mathrm{w} / \mathrm{v})$ was omitted, only 20-40 $\mu \mathrm{g}$. organism $/ \mathrm{ml}$. was obtained; yeast extract could be replaced by Tryptone (Difco; $0 \cdot 1, \mathrm{w} / \mathrm{v}$ ) or acid-hydrolysed casein (Oxoid; $0 \cdot 1, \mathrm{w} / \mathrm{v}$ ) but not by the ash of yeast extract (added equiv. $0 \cdot 1 \%, \mathrm{w} / \mathrm{v}$, original material).

Sulphate reduction. Cultures in medium $\mathrm{C}+$ thiolacetate were analysed iodometrically for sulphide; in 5 days the sulphide concentration was $3 \cdot 2 \mu$ mole $\mathrm{S}^{\prime \prime} / \mathrm{ml}$. (108 p.p.m. $\mathrm{H}_{2} \mathrm{~S}$ ). An 8-day culture was analysed for sulphide, lactate (Neish, 1950) and acetate (Grossman \& Postgate, 1955). It contained: 8.6 $\mu$ mole $\mathrm{S}^{\prime \prime} / \mathrm{ml}$. (292 p.p.m. $\mathrm{H}_{2} \mathrm{~S}$ ); $19.5 \mu$ mole lactate $/ \mathrm{ml}$. (content of uninoculated medium: $35 \mu$ mole $/ \mathrm{ml}$., hence $15.5 \mu \mathrm{mole} / \mathrm{ml}$. utilized); $17 \mu$ mole acetate $/ \mathrm{ml}$. These figures are reasonably consistent with the equation:

$$
2 \mathrm{CH}_{3} \mathrm{CHOH} . \mathrm{COOH}+\mathrm{Na}_{2} \mathrm{SO}_{4}=\mathrm{Na}_{2} \mathrm{~S}+\mathrm{CH}_{3} \mathrm{COOH}+\mathrm{CO}_{2}+2 \mathrm{H}_{2} \mathrm{O} \text {, }
$$

which is well established for Desulphovibrio desulphuricans and thermophilic sulphate-reducing bacteria. Growth in medium $\mathbf{C}$ took place when the sulphate was replaced by $\mathrm{Na}_{2} \mathrm{SO}_{3}$ or $\mathrm{Na}_{2} \mathrm{~S}_{2} \mathrm{O}_{3}$, but not $\mathrm{Na}_{2} \mathrm{~S}_{4} \mathrm{O}_{6}$.

Utilization of carbon sources. This question was not studied exhaustively and only compounds relevant to the classification of known sulphate-reducing species were tested. The organism did not grow when acetate, propionate or butyrate replaced lactate in media $\mathrm{A}$ or $\mathrm{C}$. When pyruvate replaced lactate in medium $\mathrm{C}$ the organism grew, but to no greater extent than with lactate (Senez, 1951, showed improved growth of marine Desulphovibrio desulphuricans in media having the formula of medium $\mathrm{C}$ but containing pyruvate in place of lactate). In the absence of sulphate, pyruvate did not permit growth; with certain strains of $D$. desulphuricans pyruvate will support 'sulphate-free' growth (Postgate, 1952).

Nitrate reduction. This was not detected by the micro-method of Clarke \& Cowan (1952); a parallel control with Chromobacterium prodigiosum showed nitrate reduction.

Gelatinase formation. Gelatinase was not detected by Clarke \& Cowan's (1952) procedure, though it was present in a control suspension of Chromobacterium prodigiosum. 
Cytochromes and other pigments. Heavy suspensions of organisms (c. $35 \mathrm{mg}$. dry wt./ml.) showed a faint broad absorption band at $c .557 \mathrm{~m} \mu$ when observed in a Hartridge reversion spectroscope; this band disappeared on shaking in air. Treatment with alkaline pyridine and dithionite gave a 'haemochromogen' band at $c .554 \mathrm{~m} \mu$, suggesting the presence of a protohaem derivative. No haemoprotein appeared in solution when organisms were boiled, treated with a cationic detergent, or when acetone-dried organisms were extracted with phosphate buffer. This behaviour is not characteristic of cytochrome $c_{3}$ (the cytochrome of Desulphovibrio desulphuricans; see Postgate, 1956), but it implies the presence of relatively small amounts of an insoluble cytochromelike pigment.

No absorption bands in the neighbourhood of $630 \mathrm{~m} \mu$ were seen, and suspensions of organisms did not fluoresce red when treated with alkali and exposed to light at $365 \mathrm{~m} \mu$; hence the pigment desulphoviridin, characteristic of Desulphovibrio desulphuricans (Postgate, 1956), was absent.

Hydrogenase. Suspensions of the organism (equiv. c. $0.8 \mathrm{mg}$. dry wt. organism $/ \mathrm{ml}$.) did not decolorize methylene blue $(0.05 \mu \mathrm{M})$ faster than controls (c. $3 \mathrm{hr}$. at $37^{\circ}$ ) in Thunberg tubes at $\mathrm{pH} \mathrm{7.0.} \mathrm{A} \mathrm{similar} \mathrm{suspension} \mathrm{did} \mathrm{not}$ absorb $\mathrm{H}_{2}$ in Warburg manometers when incubated for $1 \mathrm{hr}$. at $37^{\circ}$ with methyl violet. This dyestuff is among the more sensitive indicators of hydrogenase (King \& Winfield, 1955; Littlewood \& Postgate, 1956). Suspensions of equiv. c. $8 \mathrm{mg}$. dry wt. organism/ml. did not release gas from pyruvate in similar conditions (Desulphovibrio desulphuricans dismutes pyruvate to products including $\mathrm{H}_{2}, \mathrm{CO}_{2}$ and acetate; Senez, 1954). These observations indicate that hydrogenase was absent.

Sporulation. Efforts were made to observe spores in cultures of the new organism, but the morphological picture was confused by the frequent presence of granular forms. Cultures were inspected at ages ranging from $24 \mathrm{hr}$. to several months; crushed colonies in agar (which show sporulation of Clostridium nigrificans well) were inspected, and so were cultures grown with $100 \mu \mathrm{g}$. $\mathrm{MnCl}_{2} \cdot 4 \mathrm{H}_{2} \mathrm{O} / \mathrm{ml}$. (which induces spore formation in $C$. nigrificans according to a personal communication from Professor O. B. Williams). None of these expedients induced unequivocal sporulation, nor did culture with $1.5 \%$ Tryptone (Hitzman, Halvorson \& Ukita, 1957), exposure to air, glucose $(1 \%, w / v)$ or distilled water, nor yet acclimatization to growth at $42^{\circ}$. Cultures of the organism were rendered sterile by heating to $80^{\circ}$ for $1 \mathrm{~min}$. Dr A. R. Prévot, however, reported sporulation of this strain, and said: 'La sporulation apparait rarement; mais il s'agit d'une spore presque centrale, plus large que le vibrion, ne ressemblant en rien aux spores clostridiennes de C. nigrificans. Nous ignorons tout du déterminisme de cette sporulation. Mais une fois de plus j'ai observé que, quand elle apparait, elle confère à la culture ou elle se trouve une légère thermorésistance: 5 minutes à $80^{\circ}$ alors que les cultures non-sporulées sont tuées à $70^{\circ}$ ( Dr A. R. Prévot, personal communication). We have since been able to repeat all of $\mathrm{Dr}$. Prévot's observations on sporulation and on three occasions have observed c. $90 \%$ sporulation in ordinary cultures. 
Temperature range. The organism was isolated at $30^{\circ}$; it grew readily at $37^{\circ}$ though not above $40^{\circ}$. By successive subculture with temperature increments of $1^{\circ}$ it was 'trained' to grow at $42^{\circ}$. It did not then grow at $42.5^{\circ}$; adaptation to a truly thermophilic habit did not occur. During training swollen forms of the vegetative organism appeared but such morphological changes were only temporary.

\section{DISCUSSION}

The strain described here is physiologically and morphologically different from Desulphovibrio desulphuricans and $D$. aestuarii. Its inability to oxidize acetate, propionate or butyrate distinguishes it from $D$. rubentschikii and from $D$. rubentschikii var. anomalous; its mesophilic habit and failure to adapt to thermophily, together with its different morphology, distinguishes it from Clostridium nigrificans. It differs from Hvid-Hansen's Desulphoristella in its motility, its larger size, and its inability to utilize acetate or gaseous $\mathbf{H}_{\mathbf{2}}$. Its morphology and physiology, while not necessarily implying a phylogenetic relationship to members of the genus Desulphovibrio, nevertheless provide reasons for its incorporation in the same genus. In view of its origin far to the east of the meridian of Greenwich we propose the specific designation orientis; in the classification used by Prévot (1957) it would become Sporovibrio orientis. A formal description of the species follows.

\section{Desulphovibrio orientis n.sp.}

Curved rods, sometimes paired or in short chains, $c .4 \cdot 8 \times 1 \cdot 5 \mu$, spores rare, central or paracentral. One or two polar or near-polar flagella.

Motile (non-progressive), non-capsulate, Gram-negative.

Obligate anaerobe, optimum temperature range $30-37^{\circ}$.

Grows slowly on specialized media containing lactate, sulphate and thiolacetate; utilizes pyruvate in place of lactate, but not butyrate propionate or acetate. Reduces sulphates to sulphide; forms black colonies in agar media containing ferrous salts.

Nitrate not reduced.

Gelatin not hydrolysed.

Contains a cytochrome pigment; desulphoviridin absent.

Hydrogenase absent.

Isolated from a soil sample from Singapore.

Subculture deposited with the National Collection of Industrial Bacteria, National Chemical Laboratory, Teddington, England; strain no. 8382.

We are indebted to Dr A. R. Prévot for examining the organism and for giving us his views on its nomenclature; he is not entirely in agreement with us about the broader nomenclature of the sulphate-reducing bacteria and we accept full responsibility for the final decision. We are also indebted to $\mathbf{M r} \mathbf{E}$. Carlos of the Singapore Municipality and Dr J. J. Bagchi of the Indian Department of Defence for providing samples for examination. This paper is published by permission of the Director, National Chemical Laboratory. 


\section{REFERENCES}

BAARS, J. K. (1930). Over sulfaatreductie door bacterien. Dissertation; Meinema: Delft.

BEIJERINCK, M. W. (1895). Über Spirillum desulfuricans als Ursache von Sulfatreduktion. Zbl. Bakt. (2. Abt.) 1, 1, 49, 104.

Butuin, K. R., Adams, M. E. \& Thomas, M. (1949). The isolation and cultivation of sulphate-reducing bacteria. J. gen. Microbiol. 3, 46.

Campbell, L. L., Frank, H. A. \& Hall, E. R. (1957). Studies on thermophilic sulphate-reducing bacteria. I. Identification of Sporovibrio desulfuricans as Clostridium nigrificans. J. Bact. 73, 516.

Clatke, P. H. \& Cowan, S. T. (1952). Biochemical methods for bacteriology. J. gen. Microbiol. 6, 187.

Delden, A. van (1903). Beitrag zur Kentniss der Sulfatreduktion durch Bakterien. Zbl. Bakt. (2. Abt.), 11, 81, 113.

Elion, L. (1925). A thermophilic sulphate-reducing bacterium. Zbl. Bakt. (2. Abt.), $63,58$.

Grossman, J. P. \& Postgate, J. R. (1953). Cultivation of sulphate-reducing bacteria. Nature, Lond. 171, 600.

Grossman, J. P. \& Postgate, J. R. (1955). The metabolism of malate and certain other compounds by Desulphovibrio desulphuricans. J. gen. Microbiol. 12, 429.

Hitzman, D. O., Halvorson, H. O. \& Ukita, T. (1957). Requirements for production and germination of spores of anaerobic bacteria. J. Bact. 74, 1.

Hvid-Hansen, N. (1951). Sulphate-reducing and hydrocarbon-producing bacteria in ground-water. Acta path. microbiol. scand. 29, 314.

King, N. K. \& Winfield, M. E. (1955). The assay of soluble hydrogenase. Biochem. biophys. Acta, 18, 431.

Littuewood, D. \& Postgate, J. R. (1956). Substrate inhibition of hydrogenase enhanced by sodium chloride. Biochim. biophys. Acta, 20, 399.

NeIsH, A. C. (1950). Analytical methods for bacterial fermentation. Rep. nat. Res. Coun. Can. no. 46-8-3. Saskatoon.

Postgate, J. R. (1952). Growth of sulphate-reducing bacteria in sulphate-free media. Research, 5, 189.

Postgate, J. R. (1953). On the nutrition of Desulphovibrio desulphuricans: a correction. J. gen. Microbiol. 9, 440.

Postgate, J. R. (1956). Cytochrome $c_{3}$ and desulphoviridin; pigments of the anaerobe Desulphovibrio desulphuricans. J. gen. Microbiol. 14, 545.

Prévot, A. R. (1948). Recherches sur la réduction des sulfates et des sulfites minéraux par les bactéries anaérobies. Ann. Inst. Pasteur, 75, 571.

Prévot, A. R. (1957). Manuel de classification et de détermination des bactéries anaérobies, 3rd ed. Paris: Masson and Co.

Senez, J. C. (1951). Étude comparative de la croissance de Sporovibrio desulfuricans sur pyruvate et sur lactate de soude. Ann. Inst. Pasteur, 80, 395.

SEnez, J. C. (1954). Fermentation de l'acide pyruvique et des acides dicarboxyliques par les bactéries anaérobies sulfato-réductrices. Bull. Soc. Chim. biol. Paris, 36, 541.

STARKEY, R. L. (1938). A study of spore formation and other morphological characteristics of Vibrio desulfuricans. Arch. Mikrobiol. 9, 268.

ZoBeuL, C. E. (1948). In Bergey's Manual of Determinative Bacteriology (ed. Breed, Murray, \& Hitchens), 6th ed. p. 207. Baltimore, U.S.A.: Williams and Wilkins. 